\title{
DEM-based Geomorphological Mapping and Landforms Characterization of a Tropical Karst Environment in Southeastern Brazil
}

\author{
Guilherme P.B. Garcia \\ Institute of Geosciences, University of São Paulo, São Paulo, 05508-080, Brazil \\ Carlos H. Grohmann \\ Institute of Energy and Environment, University of São Paulo, São Paulo, 05508-010, Brazil
}

\begin{abstract}
This work presents a 1:10,000 geomorphological mapping of an area in southeastern Brazil, based on morphometric analysis of Digital Elevation Models (DEMs), while classical methods focus on photo interpretation. Data derived from the DEM include elevation, slope gradient, slope aspect, vertical and horizontal curvatures, amplitude, elongation and wavelength of landforms. These parameters were used along with slope shape and drainage patterns to classify the landforms according to the Land Systems method, in which portions of the landscape that presents similar terrains attributes are grouped from regional (low detail) to local (high detail) scales, respectively, Land Systems, Land Units and Land Elements. The São Paulo State geomorphological map at 1:1,000,000 scale is considered the best reference source, and was compared with the results obtained in this project. Two Land Systems, four Land Units and twelve Land Elements were identified in the study area. In this area, karst terrains are common and easily identified due their characteristics drainage patterns, amplitude and slope gradient. Karst terrain boundaries defined in this study do overlap with those defined in the state map, however the morphometric analysis allowed a better description of the terrain attributes used to define them. The terrain attributes derived automatically from the DEM enabled an accurate geomorphological classification of the study area. The methodology presented in this paper is considered effective for mapping landforms at a detailed scale and can be employed in regional scale mapping using coarser resolution DEMs.

Keywords: Geomorphology, Geomorphometry, Karst, Digital Elevation Model, Land Systems, Ribeira River
\end{abstract}

\section{Introduction}

Technological development in the past decades allowed an exponential growth of computational resources in Earth Surface analysis and mapping, where airborne (i.e., Light Detection and Ranging(LiDAR), Unmanned Aerial Vehicles (UAVs)) and satellite-based topographic data support the

\footnotetext{
Email addresses: guilherme.pereira.garcia@usp.br (Guilherme P.B. Garcia), guano@usp.br (Carlos H Grohmann)

URL: http://igc.usp.br (Guilherme P.B. Garcia), http://iee.usp.br (Carlos H. Grohmann)
} 
analysis of physical features of landscape directly from Digital Elevation Models (DEMs) (McKean and Roering, 2004; Ardizzone et al., 2007; Jaboyedoff et al., 2012; Guzzetti et al., 2012).

Topographic data remains the primary source of information for many Earth Science studies such as geomorphology and landscape development (Franklin, 1987; Pike, 1995; Evans, 1998; Schmidt and Andrew, 2005; Erskine et al., 2007; Minár and Evans, 2008; Pike et al., 2009); risk assessment (Metternicht et al., 2005; Ghuffar et al., 2013; Wang et al., 2013); landslide identification and mapping (McKean and Roering, 2004; Glenn et al., 2006; Ardizzone et al., 2007; Eeckhaut et al., 2007; Booth et al., 2009; Sterzai et al., 2010; Jaboyedoff et al., 2012; Guzzetti et al., 2012); and morphotectonics (Hiruma and Riccomini, 1999; Modenesi-Gauttieri et al., 2002; Grohmann et al., 2007). While terrain attributes derived from DEMs enable an accurate characterization of the landscape at both regional and local scales, the occurrence of errors and artifacts due to data noise, pixel size, reprojection, interpolation method and others, still pose a substantial problem (Garbrecht and Martz, 1994; Hengl, 2006; Raaflaub and Collins, 2006; Grohmann and Steiner, 2008; Hebeler and Purves, 2009), which must be addressed before any analysis.

Digital elevation data allows better land surface segmentation because it uses quantitative models based on morphometric attributes for relief classification, distinguished from qualitative and semiquantitative models predominantly used in traditional studies (Blaszczynski, 1997; Wilson and Gallant, 2000; Schmidt and Hewitt, 2004). Digital mapping methods can provide more detailed and precise maps which improve terrain information and are easier to handle in Geographic Information Systems (GIS) (Franklin, 1987; Moore et al., 1991; Blaszczynski, 1997; Minár and Evans, 2008). The importance of reliable geomorphological mapping lie with its interaction with other environmental studies (Minár and Evans, 2008).

For some parts of Brazil, geomorphological maps are not commonly updated and usually are presented at regional scales that generalize land surface information, even though important surface features exist in the territory. Many maps date from decades ago and were generated using traditional methods, usually fieldwork and aerial photo interpretation. To perform new land surface mapping in this manner would be costly, but digital mapping from existing topographic data is feasible and should enhance existing surface information depending on the scale of analyis.

The main goal of this research was to generate a geomorphological map based exclusively on attributes derived from a DEM generated from topographic maps, and compared to a traditional (i.e., manual) geomorphological mapping method.

\section{Study Area}

The area selected for this study is a hilly, forested, region in southeastern Brazil, renowned for the occurrence of karst features in its Natural Reserves. It is located in the upper Ribeira river valley in the southern part of São Paulo State (Fig. 1) covering $714 \mathrm{~km}^{2}$ (17 km x $42 \mathrm{~km}$ ) and between UTM coordinates N 7270000/7290000 and E 720000/770000 (zone 22J, southern hemisphere). The region is characterized by a landscape of hills and ridges with dense Atlantic Forest coverage preserved in conservation units, agricultural areas, and small towns and villages. The climate is humid subtropical, with a hot and rainy summer and without a typical dry season in the winter ( $\mathrm{Cfa}$ and $\mathrm{Cfb}$ of Koppen, 1948). The main conservation unit in the area is the Upper Ribeira State Park (PETAR - Parque Estadual Turistico do Alto Ribeira), created in 1958 for the purpose of protecting the caves and surrounding forest.

Geologically, the area is within the Mantiqueira Province, Apiai Domain (Hasui, 2012), and is composed mainly of supracrustal rocks of low to medium metamorphic degree of the Açungui Group and gneiss-migmatite basement (Fig. 2A). The Açungui Group comprises intercalated layers of metasediments in NE-SW oriented bands controlled by shear zones (Campanha and Sadowski, 1999; Heilbron et al., 2004). The limestones in the area belong to the Middle Proterozoic Lajeado Subgroup (Campanha and Sadowski, 1999). Predominance of carbonate rocks occur in the West portion of the study area while pelitic rocks are abundant in the East.

The geomorphology of the region (Fig. 2B), located in the transition zone between the Atlantic Plateau (locally known as the Guapiara Plateau) and the Coastal Lowlands, is marked by a 
mountainous landscape with a maximum altitude above $1000 \mathrm{~m}$ and deep valleys with up to $800 \mathrm{~m}$ in amplitude. A pattern of polygonal karst with deep blind valleys and karstic canyons distinguishes the Ribeira Valley karst from other Brazilian karst regions Auler and Farrant (1996). According to Karmann and Ferrari (2000), the Ribeira Valley karst "stands out for its steep hydraulic gradients, its important allogenic recharge and incised underground drainage with vadose canyons up to $60 \mathrm{~m}$ deep, where vertical caves or abysses and huge collapse halls are common".

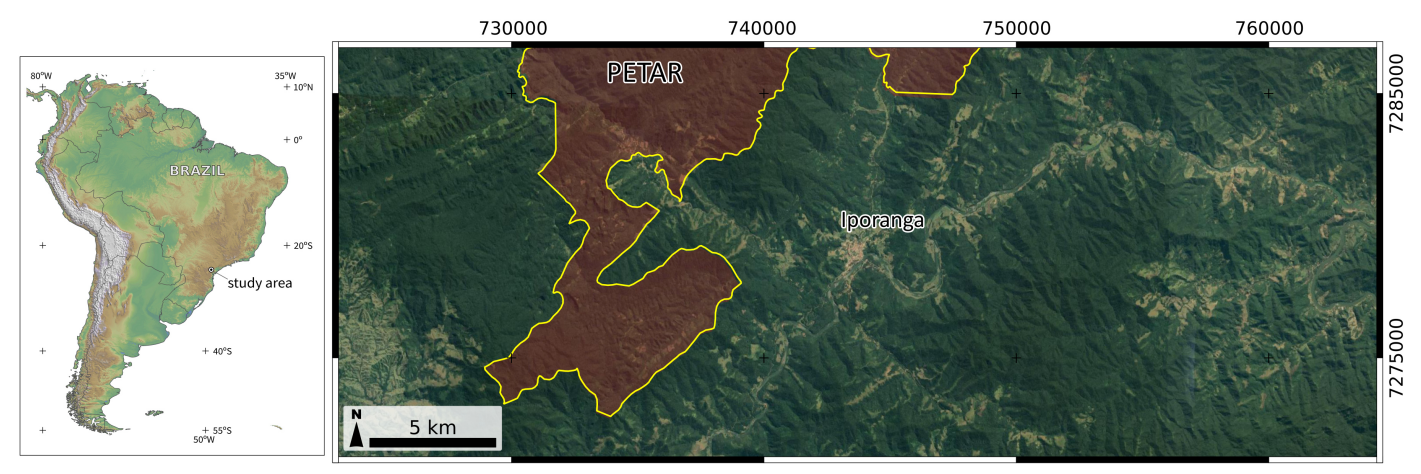

Figure 1. Location of study area in Southeastern Brazil, highlighting the southern portion of the Upper Ribeira State Park (PETAR). UTM coordinates, zone 22J (Southern hemisphere).

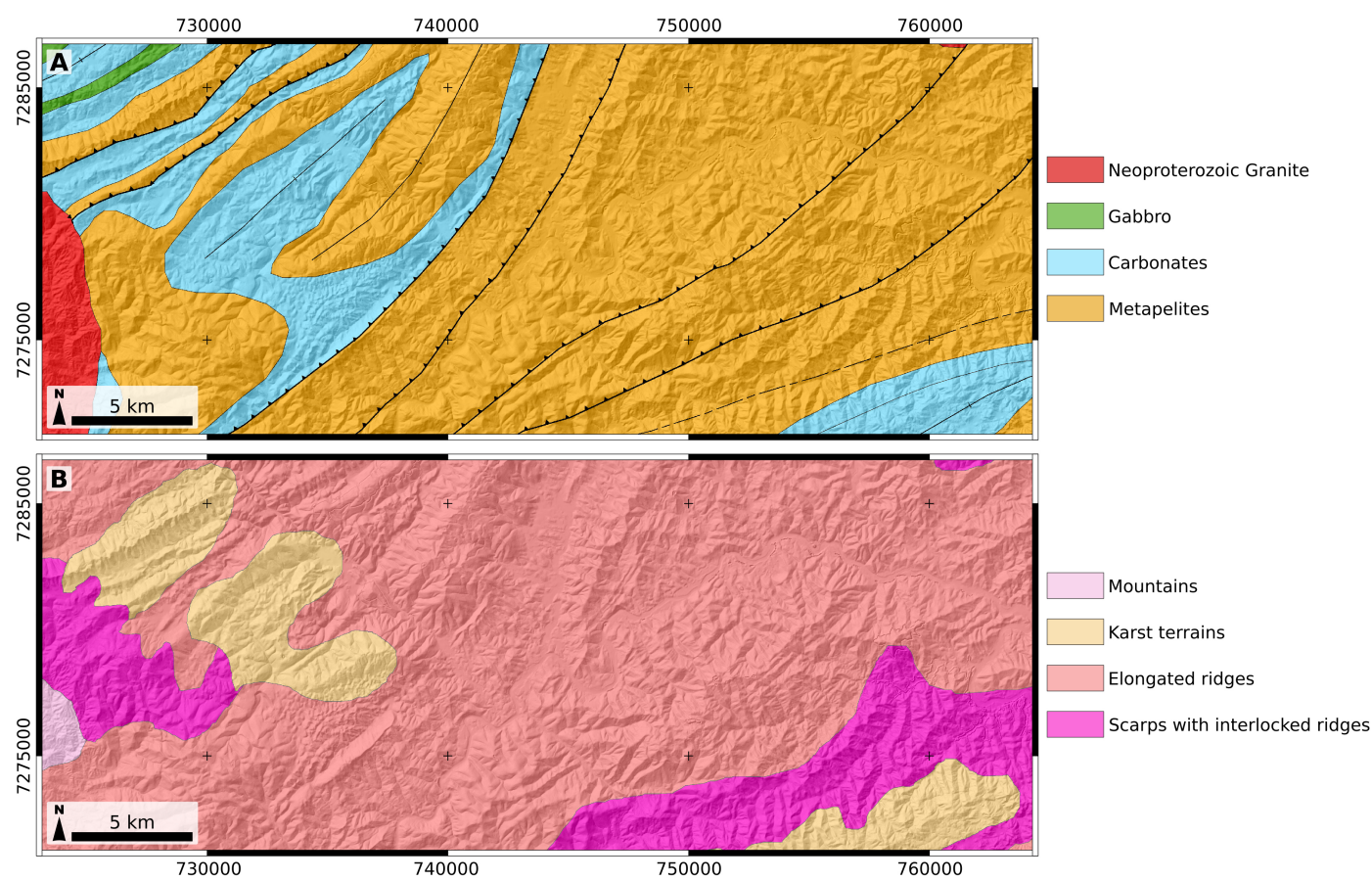

Figure 2. A) Simplified geological map of the study area. Modified from Campanha and Sadowski (1999) and Karmann and Ferrari (2000). B) Geomorphological map for the study area (Ponçano, 1981, original scale of 1:1,000,000). UTM coordinates, zone 22J (Southern hemisphere). 


\section{Methods}

\subsection{Morphometric Analysis}

The input data for morphometric analysis and morphological mapping consisted of a DEM with a $10 \mathrm{~m}$ spatial resolution, generated by the interpolation of contour lines and height points digitized from a 1:10.000 topographic map. The interpolation was carried out with Regularized Splines with Tension (Mitasova and Mitas, 1993; Mitasova and Hofierka, 1993; Mitasova et al., 2005), a robust method which allows the adjustment of mathematical parameters for tension and smoothness of the resulting surface (v.surf.rst tool from GRASS-GIS v.6.4).

Using a combination of ArcGIS v.10 (ESRI, 2011) and GRASS-GIS v.6.4 (Neteler et al., 2012; GRASS Development Team, 2015), the following terrain attributes were derived from the DEM: hypsometry, slope, plan (horizontal) and profile (vertical) curvatures. The drainage network and watershed basins were calculated in ArcGIS with a threshold of 100 cells. Morphostructural lineaments (O'Leary et al., 1976) were interpreted from a set of eight shaded relief images with illuminant positioned at $45^{\circ}$ intervals, since the scene illumination will enhance linear features which are perpendicular to lighting, in spite of parallel ones (Grohmann, 2004; Smith and Wise, 2007). Other parameters such as extent, elongation and wavelength of individual landforms were manually extracted using ArcGIS on-screen measuring tools.

\subsection{Geomorphological Mapping}

Geomorphological mapping was carried out according to the land systems method, based on the classification of areas with similar physical features and terrain attributes, which are distinct from the adjacent portions (Christian et al., 1953; Christian, 1958; Ponçano et al., 1979; Ponçano, 1981).

Land systems show the main structures of a landscape at a regional scale, being divided into minor and more detailed land portions, namely land units and land elements. A land unit is a homogeneous tract of land at a given scale (Zonneveld, 1989) that can be described similarly in terms of its topography, soil, lithology and vegetation (Christian, 1958), such as scarps, hills, alluvial fans. Land elements are the components of land units and can be represented, for instance, by the crest, hillside or footslope of a given scarp (Ponçano, 1981).

The mapping was performed manually in ArcGIS, delineating and encompassing portions with similar morphometric characteristics that fit land unit and land element definitions. All terrain attributes derived from the DEM were used in the mapping process.

\subsection{Karst Landform Mapping}

Karst landforms are the most significant landscape features in the study area due their hydrological and morphological attributes. Karst landscapes are the result of complex combinations between geology, climate, topography, hydrology and biological factors over time (Stokes et al., 2010). Karst surface landforms are generally classified according to their scale, distinguishing input, residual and output features (De Waele et al., 2009). Surface drainage in karst terrain is an important mapping feature since underground drainage is predominant (Summerfield, 1991; De Waele et al., 2009; Hardt et al., 2010; Stokes et al., 2010). Sinkholes and resurgences (karst springs) impose a chaotic pattern to the stream network that allows the identification of karst areas.

Karst landforms can be identified from a DEM and derived terrain attributes by surface disturbance caused mainly by meso to macro scale features, such as dolines and poljes in a well developed karst environment (Summerfield, 1991; Stokes et al., 2010). Automated methods for karst identification using DEM input data have been performed by several researchers (e.g., Anders et al., 2011; Doctor and Young, 2013; Wu et al., 2016).

Carvalho Júnior et al. (2013) proposed a method for automatic delimitation of karst landforms based on simple DEM operations. First, a depression-filling algorithm is applied to a DEM. Such algorithms are commonly utilized as a pre-processing step in geomorphological or hydrological analysis to produce a "depressionless" DEM in which the elevation of cells contained in depressions 
are raised to the lowest elevation value on the boundary of the depression (Jenson and Domingue, 1988; Planchon and Darboux, 2001; Lindsay et al., 2004; Lindsay and Creed, 2006).

The procedure fills all depressions in the DEM, not only those considered as erroneous data, but also those that represent real topographic features such as river valleys and karstic depressions (dolines, poljes, polygonal basins). A second step is a subtraction between the filled and the original DEMs. This will result in a map of the filled areas, which is then compared with the geology and geomorphology of the study area to delineate karst terrain (Carvalho Júnior et al., 2013; Kakavas et al., 2015, 2018).

\section{Results and Discussions}

\subsection{Morphometry}

The hypsometric map of the study area, classified in elevation intervals of $50 \mathrm{~m}$, is presented in Fig. 3A. Elevation is commonly below $450 \mathrm{~m}$ with altimetric amplitude around $300 \mathrm{~m}$, although it can reach $900-1,100 \mathrm{~m}$ in the central-west, Northwest and Southeast portions of the area, with amplitude around 400-500 m, and frequently associated with karstic landforms. In the karstic areas, drainage carving is common, as well as the presence of escarpments without a main orientation or structural control.

The slope map of the area is presented in Fig. 3B. Low slope values are associated with streams and valleys in karstic areas and in the Ribeira river. Slope angles above $20^{\circ}$ are predominant. High slope values, usually above $40^{\circ}$, are common in the whole area with a high concentration in the North-Northwest portion, within karstic areas or associated with shear zones and geological contacts between carbonate and non-carbonate rocks.

Maps of horizontal and profile curvature are depicted in Fig. 3C and Fig. 3D, respectively. Convex horizontal curvature indicates flow divergence and rounded landforms while concave ones represent accumulation zones at the footslopes. Convex vertical curvature represents acceleration flow towards the footslope, and concave, deceleration. The horizontal curvature map shows the predominance of convex and flat surfaces; convex forms occur over the whole study area and does not have a lithological or structural control. Flat surfaces describe hillsides, streams and valleys. Concave surfaces are commonly related to steep slopes and high amplitudes occurring mainly in the East-Southeast portion of the area.

On the profile curvature map, flat and concave surfaces are predominant and mainly related to areas of high drainage density. Flat surfaces are abundant over the whole study area with no evidence of a lithological or structural control. Concave surfaces are related to valleys and degradation relief, they are also lithology independent and their presence in karst terrain can be related to depressions such as dolines and poljes. Convex surfaces are uncommon, occurring essentially on hilltops. 

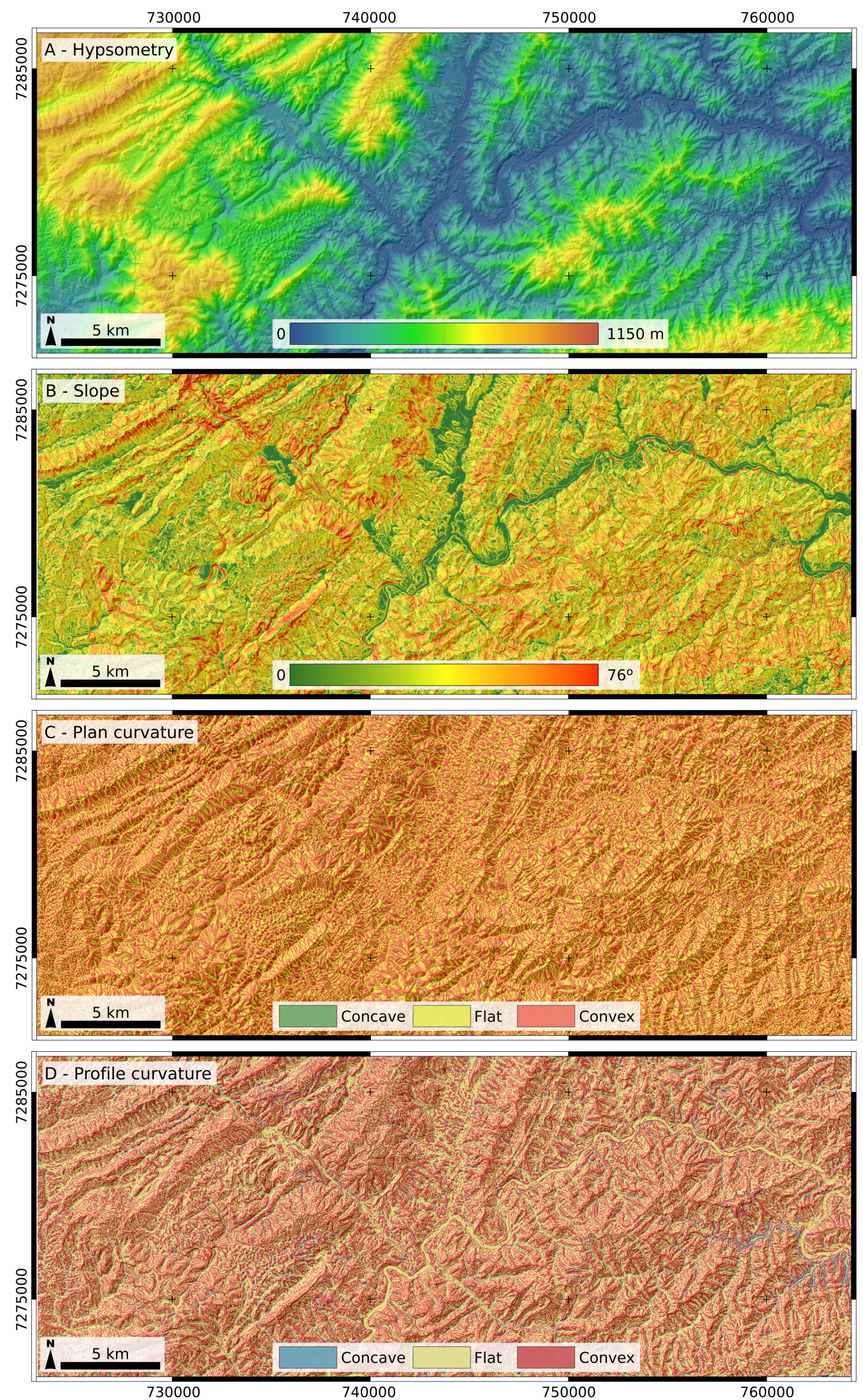

Figure 3. Morphometric maps of the study area. A) Hypsometry; B) Slope; C) Plan curvature; D) Profile curvature. UTM coordinates, zone 22J (Southern hen6isphere). 


\subsection{Drainage Network Analysis}

The drainage network map (Fig. 4) was superimposed on the other maps (geology, geomorphology, thematic maps) for pattern analysis. Superficial features and morphometric terrain characteristics are strongly associated with the surficial drainage network. Dendritic patterns are predominant in the study area, however structural control by the shear zones is evident in the NW portion where streams are remarkably straight. A radial pattern is present in the Eastern portion.

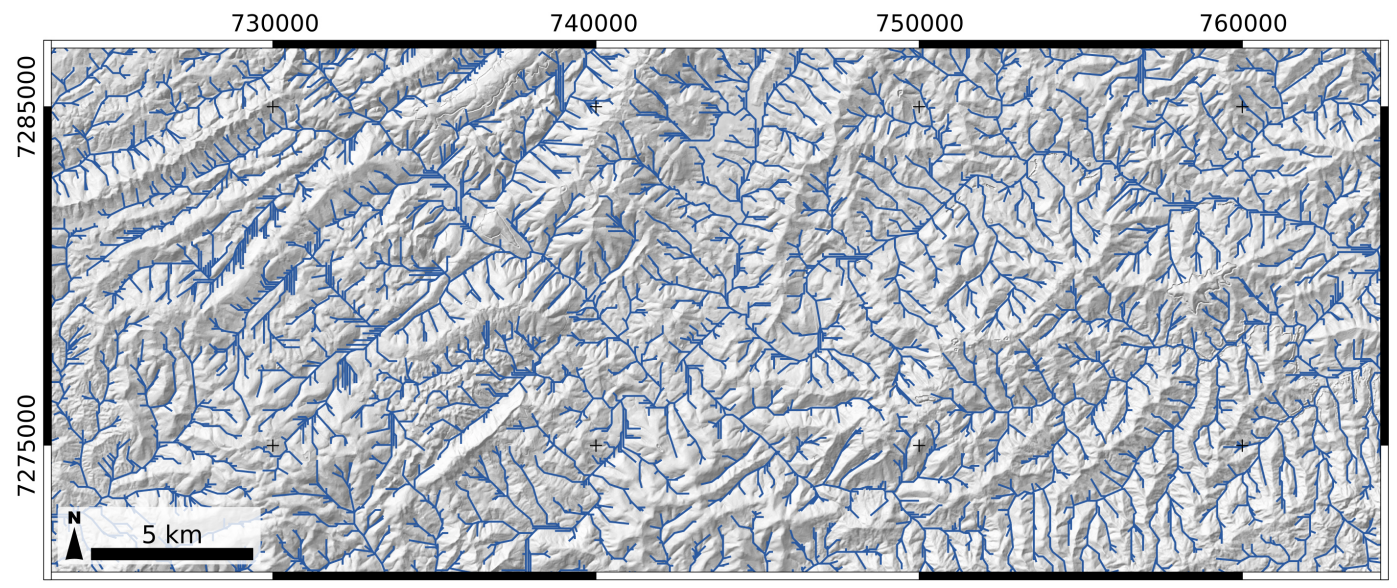

Figure 4. Drainage network over shaded relief image. UTM coordinates, zone 22J (Southern hemisphere).

\subsection{Lineament Analysis}

Manually interpreted lineaments for the study area are shown in Fig. 5, along with rose diagrams of the frequency and length of lineaments per $10^{\circ}$ interval. Two main trends are observed, at NE and at NNW. Lineaments oriented from NNE to ENE are predominant and relate to the general structural trend of the Mantiqueira Tectonic Province (Campanha and Sadowski, 1999). NNW to WNW lineaments are less abundant and are related the Ponta Grossa Arch, a NW-SE massive tectonic feature over $600 \mathrm{~km}$ long, marked by dike swarms of the Serra Geral Formation and magnetic alignments (e.g., Riccomini et al.; Strugale et al., 2007).

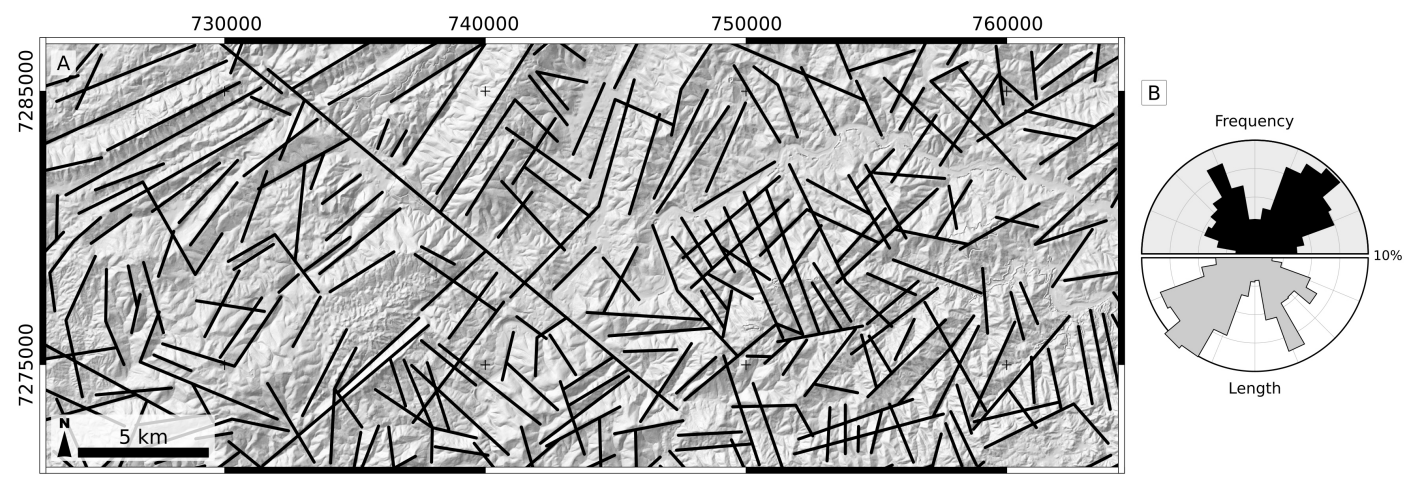

Figure 5. A) Interpreted lineaments over a shaded relief image; B) Rose diagram. UTM coordinates, zone 22J (Southern hemisphere). 


\subsection{Local Geomorphological Map}

Based on the classification of areas with similar physical features and terrain attributes (the land systems method), a geomorphological map was generated for the study area at a scale of 1:10,000 (Fig. 6). Two land systems, four land units and twelve land elements were identified in the study area. The terrain attributes for each land system, unit and element are described in Table 1. Original names for the land systems, units and elements (in Portuguese) are presented as well.

Land system delineation was undertaken manually in a GIS separating the main watersheds and encompassing those with similar morphometric, topographic and geologic characteristics. Within each land system, separation in to smaller parts (land units and land elements) was performed by comparing mainly morphometric attributes and surface curvature, adding new parameters with scale detailing.

Land systems were classified as Ridge Terrain (Relevo de Serras) and Degradation Terrain (Relevo de Degradação). Ridge Terrain shows the highest elevations, amplitudes and slopes in the study area and can be divided into two land units: Elongated Ridges (Serras Alongadas) and Karstic Terrains (Relevos Cársticos).

Elongated Ridges are the typical unit of this land system with elongated landforms, intense stream escarpment, steep slopes and high relief amplitude of landforms. These ridges are composed mainly by metasedimentary rocks of the Açungui Group, with structure (metamorphic foliation, shear zones) parallel to the elongation of landforms.

The land unit of Karst Terrain is marked by a distinct surface roughness from adjacent areas. Generally, karst areas are smoother and at lower elevations (500-800 m), amplitudes $(<400 \mathrm{~m})$ and slopes angles $\left(25^{\circ}-35^{\circ}\right)$ than those within the ridges. A dendritic drainage pattern is recognizable but it is not well defined and occurs in a dispersed way through the land elements, controlled by karst landforms such as sinkholes and depressions. Land elements in this unit are elongated landforms, sometimes lenticular, developed over carbonate rocks.

The land system of Degradation Terrain is predominant in the study area and is composed of two land units, Hills with Restricted Ridges (Morros com Serras Restritas) and Hills and Hillocks (Morros e Morrotes).

The land unit of Hills with Restricted Ridges occurs in a significant portion of the area, with high elevations, amplitudes and slopes (although slopes are lower than those in the Elongated Ridges land unit). The landforms are elongated although with significant sphericity, showing dendritic and radial drainage patterns. The radial drainage pattern is observed only in this land unit and indicates the presence of isolated topographic highs within a landscape dominated by hills, mounds and hillocks.

Hills and Hillocks is the predominant land unit in the study area, marked by a gentler and less eroded landscape with the lowest elevations of the area and moderate values of slope and amplitude. It is developed over non-carbonate metasedimentary rocks, with local occurrences of igneous (granitic) rocks. Land elements are generally smaller than those observed in the other units and can be elongated or rounded, with convex forms of hilltops and hillsides. This land unit represents a transition between Elongated Ridges and Hills with Restricted Ridges units. 


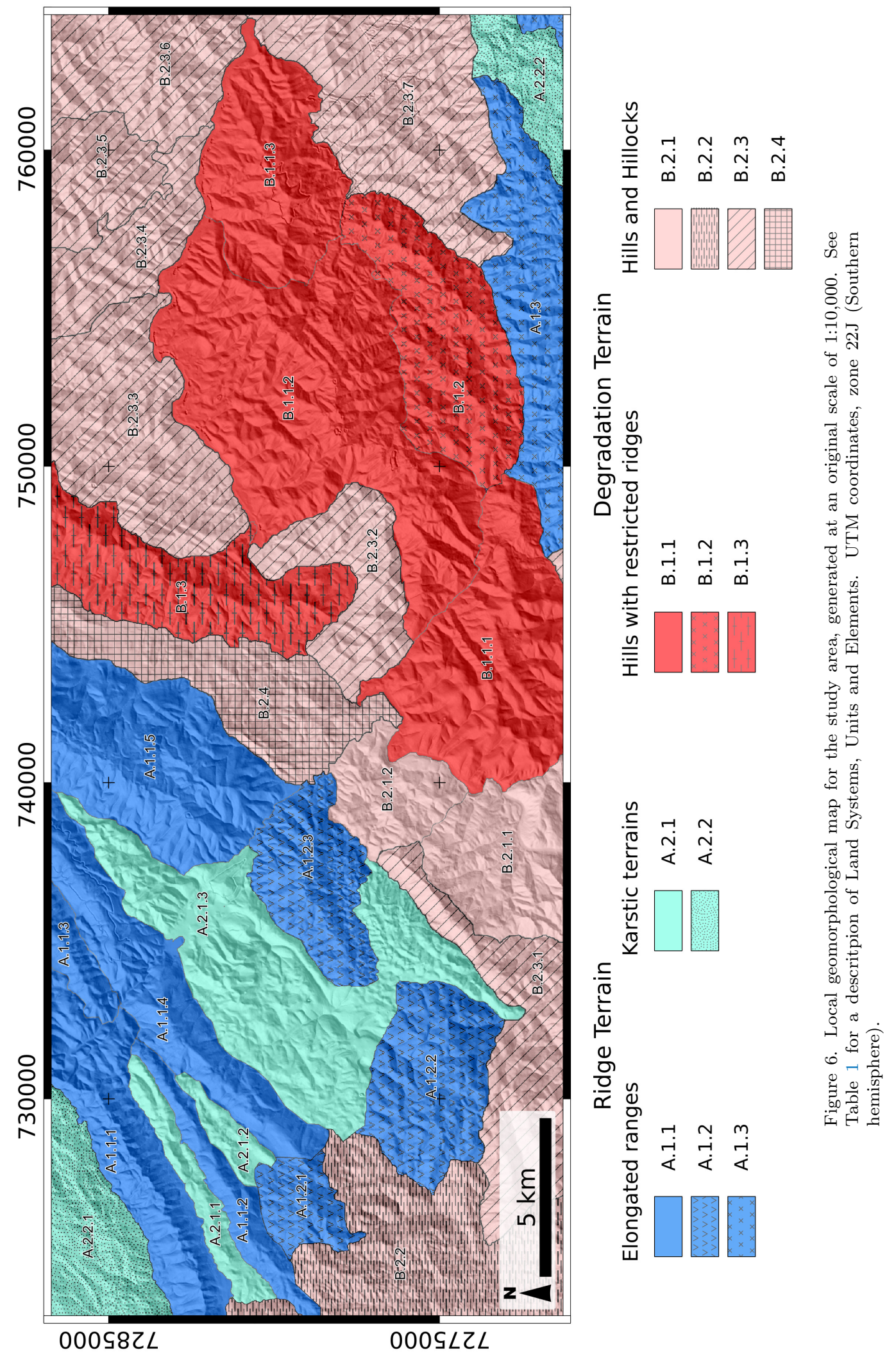


Table 1. Description of Land Systems, Units and Elements of the geomorphological map generated in this study.

\begin{tabular}{|c|c|c|c|}
\hline Land Systems & Land Units & Land Elements & Mapped Element \\
\hline \multirow[t]{5}{*}{$\begin{array}{l}\text { A: Ridge } \\
\text { Terrain }\end{array}$} & \multirow[t]{3}{*}{$\begin{array}{l}\text { A.1: Elongated Ridges: Dendritic and parallel } \\
\text { drainage patterns; maximum elevations above } \\
800 \mathrm{~m} \text {, locally above } 1000 \mathrm{~m} \text {; mean slope greater } \\
\text { than } 25^{\circ} \text {, usually above } 35^{\circ}\end{array}$} & $\begin{array}{l}\text { A.1.1 - Amplitudes usually above } 500 \mathrm{~m} \text {, maximum of } 900 \mathrm{~m} \text {; main slope greater } \\
\text { than } 30-35^{\circ}, \text { usually greater than } 45^{\circ} \text {; elongated and NE-SW oriented land- } \\
\text { forms, wavelength between } 1,000 \text { and } 2,000 \mathrm{~m} \text {, mean elongation lower than } 0.3 ; \\
\text { predominant convex surfaces }\end{array}$ & $\begin{array}{l}\text { A.1.1.1 - Palmital } \\
\text { A.1.1.2 - Roncador } \\
\text { A.1.1.3 - Onça Parda } \\
\text { A.1.1.4 - Biquinha } \\
\text { A.1.1.5 - Sem Fim }\end{array}$ \\
\hline & & $\begin{array}{l}\text { A.1.2 - Maximum amplitudes above } 600 \mathrm{~m} \text {; mean slope greater than } 20^{\circ}, \text { maxi- } \\
\text { mum at } 35-40^{\circ} ; \text { rounded and spheric landforms, wavelength between } 2,000 \text { and } \\
4,000 \mathrm{~m} \text { andm mean elongation above } 0.6 ; \text {; predominant convex surfaces }\end{array}$ & $\begin{array}{l}\text { A.1.2.1 - Bandeira } \\
\text { A.1.2.2 - Santo Antonio } \\
\text { A.1.2.3 - Bairro da Serra }\end{array}$ \\
\hline & & $\begin{array}{l}\text { A.1.3 - Maximum amplitudes below } 700 \mathrm{~m} \text {; mean slope greater than } 20^{\circ} \text {, locally } \\
\text { above } 30^{\circ} ; \text { elongated and slightly rounded landforms, wavelength between } 3,000 \\
\text { and } 4,000 \mathrm{~m} \text { and mean elongation lower than } 0.3 ; \text { concave, flat and mainly } \\
\text { convex surfaces }\end{array}$ & A.1.3 - Andorinhas \\
\hline & \multirow[t]{2}{*}{$\begin{array}{l}\text { A.2: Karstic Terrains: Unidentified drainage } \\
\text { pattern, possibly dendritic; maximum elevations } \\
\text { above } 500 \mathrm{~m} \text {, but hardly exceeds } 800 \mathrm{~m} \text {; mean } \\
\text { slopes greater than } 20^{\circ} \text { varying from } 5 \text { to } 35^{\circ}\end{array}$} & $\begin{array}{l}\text { A.2.1 - Mean amplitude above } 300 \mathrm{~m} \text {, hardly exceeds } 500 \mathrm{~m} \text {; main slope greater } \\
\text { than } 15^{\circ} \text {, locally exceeds } 355-40^{\circ} ; \text { usually elongated landforms, wavelength be- } \\
\text { tween } 700 \text { and } 3,000 \mathrm{~m} \text { and mean elongation greater than } 0.45 ; \text { predominant } \\
\text { convex surfaces, locally concave and flat }\end{array}$ & $\begin{array}{l}\text { A.2.1.1 - Furnas } \\
\text { A.2.1.2 - Santana } \\
\text { A.2.1.3 - Lajeado-Bombas }\end{array}$ \\
\hline & & $\begin{array}{l}\text { A.2.2. Maximum amplitudes below } 400 \mathrm{~m} ; \text { mean slope below } 20^{\circ} \text {, locally } \\
\text { above } 35^{\circ} ; \text { e elongated slightly rounded landforms, wavelength between } 2,000 \\
\text { and } 4,000 \mathrm{~m} \text { and mean elongation greater than } 0.4 \text {; concave and convex surfaces }\end{array}$ & $\begin{array}{l}\text { A.2.2.1 - Apiaí } \\
\text { A.2.2.2 - Tapagem }\end{array}$ \\
\hline \multirow{7}{*}{$\begin{array}{l}\text { B: Degradation } \\
\text { Terrain }\end{array}$} & \multirow[t]{3}{*}{$\begin{array}{l}\text { B.1: Hills with Restricted Ridges: Predominant } \\
\text { dendritic drainage pattern with some radial pattern; } \\
\text { maximum elevation above } 600 \mathrm{~m} \text {, peaks at } 800 \mathrm{~m} \text {; } \\
\text { mean slope greater than } 20^{\circ} \text {, hardly exceeds } 40^{\circ}\end{array}$} & $\begin{array}{l}\text { B.1.1 - Mean amplitudes between } 500 \text { and } 800 \mathrm{~m} \text {; mean slope above } 20^{\circ} \text { usually } \\
\text { greater than } 35^{\circ} ; \text {; runded and stretched landforms, wavelength between } 5,000 \\
\text { and } 9,000 \mathrm{~m} \text { and mean elongation greater than } 0.65 \text {; flat, concave and mainly } \\
\text { convex surfaces }\end{array}$ & $\begin{array}{l}\text { B.1.1.1 - Cabanas-Rio das Pedras } \\
\text { B.1.1.2 - Casteliano } \\
\text { B.1.1.3 - Munhunguara }\end{array}$ \\
\hline & & $\begin{array}{l}\text { B.1.2 - Maximum amplitudes below } 500 \mathrm{~m} \text {; mean slope greater than } 20^{\circ} \text { locally } \\
\text { above } 30^{\circ} \text {; elongated and rounded landforms, wavelength greater than } 3,000 \mathrm{~m} \\
\text { and mean elongation of } 0.5 \text {; convex and concave surfaces }\end{array}$ & B.1.2 - Jurumirim \\
\hline & & $\begin{array}{l}\text { B.1.3 - Maximum amplitudes above } 600 \mathrm{~m} \text {; mean slope greater than } 15-20^{\circ} \text {, } \\
\text { maximum at } 35^{\circ} \text {; elongated landforms, wavelength greater than } 2,000 \mathrm{~m} \text { and } \\
\text { mean elongation lower than } 0.3 \text {; concave and convex surfaces }\end{array}$ & B.1.3 - Iporanga \\
\hline & \multirow[t]{4}{*}{$\begin{array}{l}\text { B.2: Hills and Hillocks: Dendritic drainage } \\
\text { patterns, locally parallel and radial patterns; } \\
\text { maximum elevations above } 400 \mathrm{~m} \text { usually exceeds } \\
600 \mathrm{~m} \text {; mean slope greater than } 15^{\circ} \text {, ocasionally } \\
\text { above } 30^{\circ}\end{array}$} & $\begin{array}{l}\text { P. } 2.1 \text { - Amplitudes vary between } 200 \text { and } 500 \mathrm{~m} \text {; mean slope between } 15 \text { and } \\
20^{\circ} \text {, locally greater than } 30^{\circ} \text {; elongated and sub-rounded landforms, wavelengthth } \\
\text { between } 500 \text { and } 2,000 \mathrm{~m} \text { and mean elongation between } 0.4 \text { and } 0.5 \text {; convex } \\
\text { and predominant concave surfaces }\end{array}$ & $\begin{array}{l}\text { B.2.1.1 - Descalvado } \\
\text { B.2.1.2 - Taquariuva }\end{array}$ \\
\hline & & $\begin{array}{l}\text {. } 2.2 \text { - Amplitudes vary between } 300 \mathrm{and} 600 \mathrm{~m} \text {; mean slope greater than } 15^{\circ}, \\
\text { locally greater than } 35^{\circ} ; \text {; elongated and sub-rounded landforms, wavelength } \\
\text { between } 800 \text { and } 2,000 \mathrm{~m} \text { and mean elongation of } 0.4 ; \text { concave, convex and } \\
\text { mainly flat surfaces }\end{array}$ & B.2.2 - Itaoca \\
\hline & & $\begin{array}{l}\text { B.2.3 - Amplitudes vary between } 400 \text { and } 700 \mathrm{~m} ; \text { mean slope greater than } 20^{\circ} \text {, } \\
\text { usually above } 30-35^{\circ} \text {; sub-rounded slightly stretched landforms, wavelength } \\
\text { between } 1,000 \text { and } 4,000 \mathrm{~m} \text { and mean elongation greater than } 0.5 ; \text { concave, } \\
\text { convex and flat surfaces }\end{array}$ & $\begin{array}{l}\text { B.2.3.1 - Figueira } \\
\text { B.2.3.2 - Agudos Grandes } \\
\text { B.2.3.3 - Sulino } \\
\text { B.2.3.4 - Pedra Santa } \\
\text { B.2.3.5 - Pilóes } \\
\text { B.2.3.6 - Ivaporunduva } \\
\text { B.2.3.7 - Eldorado }\end{array}$ \\
\hline & & $\begin{array}{l}\text { B.2.4 - Amplitudes lower than } 500 \mathrm{~m} \text {; mean slope below } 20^{\circ} \text {, maximum at } \\
35^{\circ} \text {; elongated landforms, wavelength lower than } 3.000 \mathrm{~m} \text { and mean elongation } \\
\text { below } 0.3 \text {; convex and flat surfaces }\end{array}$ & B.2.4 - Caboclos \\
\hline
\end{tabular}

\subsection{Automatic identification of karst areas}

The automatic karst landform mapping method of Carvalho Júnior et al. (2013) generates a depression map, highlighting not only karst landforms but also valleys and drainage (Fig. 7A). True karst depressions occur in the Northwest sector of the study area (Karmann, 1994), restricted to the carbonate rocks, in a network of polygonal karst depressions (Karmann, 1994; Ferrari et al., 1998). These carbonate rock areas, locally known as Furnas-Santana and Lajeado-Bombas were mapped into five morphological zones by Karmann (1994): Fluvial, Contact, Fluviokarst, Transition and Polygonal (or composite depressions).

Areas identified as karst depressions over carbonate rocks by (Karmann, 1994) show irregular shape and correspond to the Transition and Polygonal zones (Fig. 7B). The local geomorphological map from this work also shows good agreement between land elements interpreted as karst terrain and Karmann's Polygonal, Fluviokarst and Transition zones (Fig. 7C). 

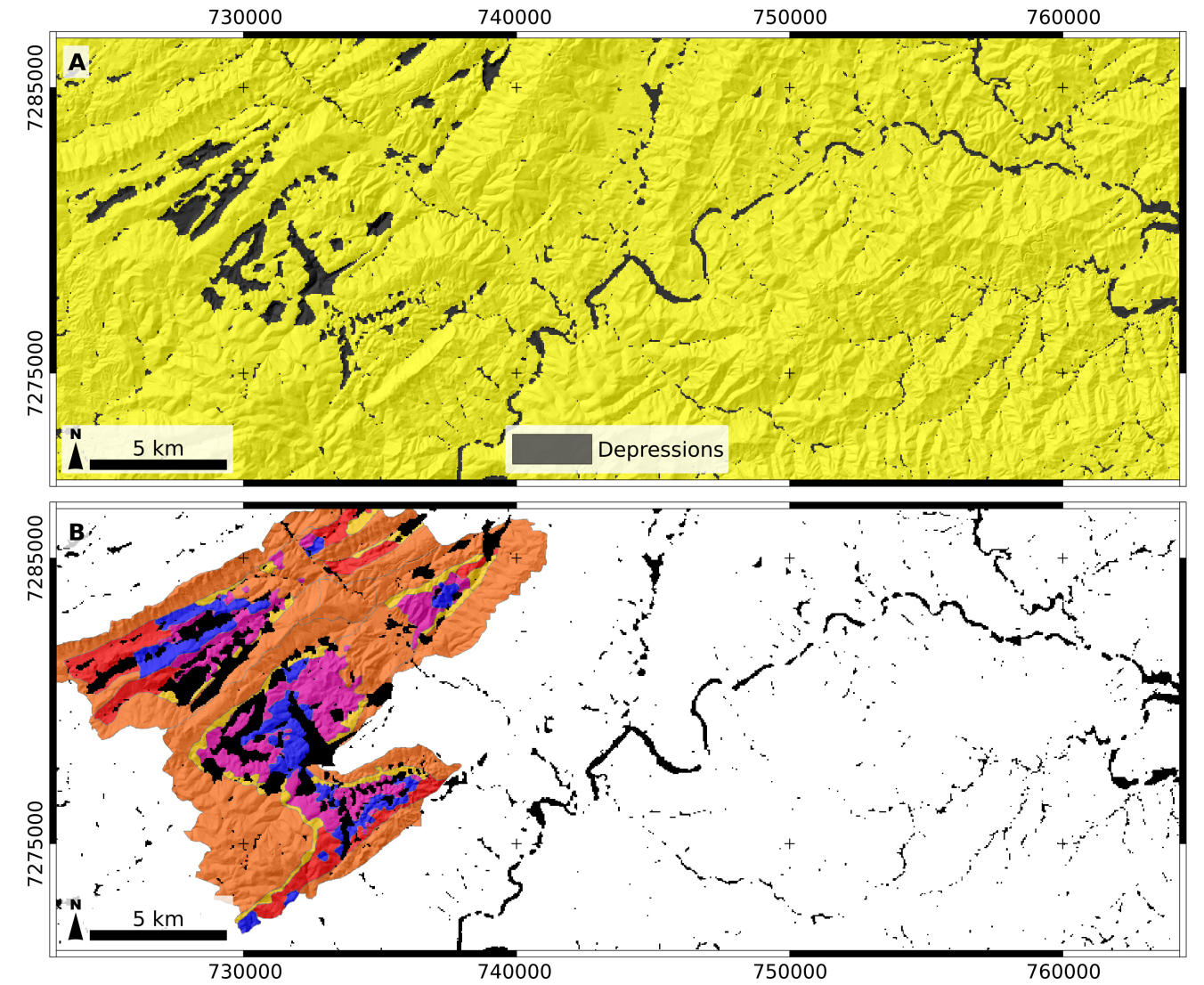

Karstic morphological zones (Karmann, 1994)
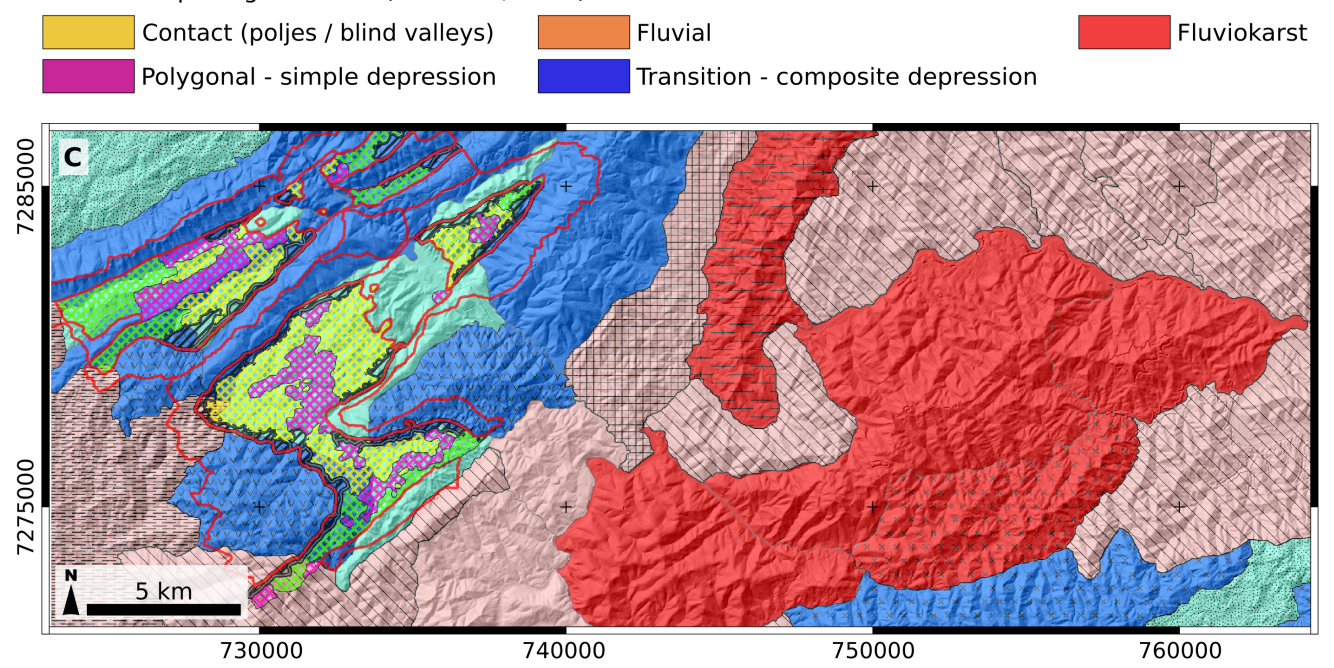

Karstic morphological zones (Karmann, 1994)

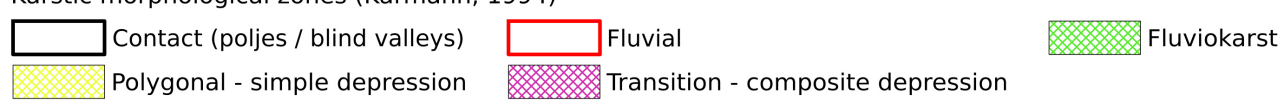

Figure 7. Automatic identification of karst areas. A) Depression Map; B) Depressions over Morphological Zones of Karmann (1994); C) Depressions over Morphological Zones of Karmann (1994) and Local Geomorphological Map from this work. UTM coordinates, zone 22J (Southern hemisphere). 


\section{Conclusions}

This paper has presented a 1:10,000 geomorphological map created using terrain attributes derived from a Digital Elevation Model and visually and objectively compared with the existing 1:1,000,000 map which was based on the traditional methods of fieldwork and photointerpretation. The study area was selected due to its characteristic landforms, such as karst terrain, and the availability of 1:10,000 topographic maps to derive the DEM.

Automatic delimitation of karst landforms resulted in a map of depressions with good correspondence between karstic zones previously identified by Karmann (1994). Karst terrain present a prominent tectonic control by the shear zones in the study area.

Compared to the São Paulo state 1:1,000,000 geomorphological map of (Ponçano, 1981), the 1:10,000 scale mapping carried out for this project identified the same Land Systems and Units, with the expected differences in their delimitation (i.e., boundaries, extension) due its larger scale. The small mapping scale of the 1981 map leads to cartographic generalization and the characterization of Land Elements can be vague, with unspecific terrain attributes for the landforms.

In the 1981 map, which was created using traditional fieldwork and aerial photograph interpretation, Land Systems are described by their morphological attributes and lithology, while Land Units and Land Elements are based on relief amplitude, slope, morphological features and drainage patterns. In this project, created with modern GIS tools and DEM geomorphometric analysis, the description and grouping of Land Units were based on similarities in DEM-extracted terrain attributes such as elevation, drainage patterns and slope angles. Specific terrain attributes like landform wavelength, mean elongation and hillslope shape were used to define the Land Elements.

The terrain attributes derived automatically from the DEM enabled an accurate geomorphological classification of the study area. The methodology presented in this paper is considered effective for mapping landforms at a detailed scale and can be employed in regional scale mapping using coarser resolution DEMs.

\section{Acknowledgments}

The authors would like to thank the graduate program in Mineral Resources and Hydrogeology (IGc-USP) and to Brazil's National Council for Scientific and Technological Development - CNPq, for a research scholarship to G.P.B. Garcia (133050/2013-0). This study was supported by the Sao Paulo Research Foundation (FAPESP) grant \#2016/06628-0 and by CNPq grant 307647/2015-3 to C.H. Grohmann, and is co-funded by FAPESP (BIOTA \#2013/50297-0), NSF (DEB 1343578), and NASA. Acknowledgments are extended to the Regional Editor, Mike J. Smith (Plymouth University) and the anonymous reviewers for their criticism and suggestions, which helped to improve this paper.

\section{Supplementary data}

Supplementary data associated with this article can be found in the online version at https: //doi.org/10.1016/j.jsames.2019.04.013.

\section{References}

Anders, N.S., Seijmonsbergen, A.C., Bouten, W., 2011. Segmentation optimization and stratified object-based analysis for semi-automatic geomorphological mapping. Remote Sensing of Environment 115, 2976-2985.

Ardizzone, F., Cardinali, M., Galli, M., Guzzetti, F., Reichenbach, P., Ardizzone, F., Cardinali, M., Galli, M., Guzzetti, F., Identification, P.R., 2007. Identification and mapping of recent rainfall-induced landslides using elevation data collected by airborne Lidar To cite this version : Identification and mapping of recent rainfallinduced landslides using elevation data collected by airborne Lidar. Natural Hazards and Earth System Science 7, 637-650.

Auler, A., Farrant, A.R., 1996. A brief introduction to karst and caves in Brazil. Proceedings of the University of Bristol Spelaeological Society 20, 187-200.

Blaszczynski, J.S., 1997. Landform characterization with geographic information systems. Photogrammetric Engineering \& Remote Sensing 63, 183-191. 
Booth, A.M., Roering, J.J., Perron, J.T., 2009. Automated landslide mapping using spectral analysis and highresolution topographic data: Puget Sound lowlands, Washington, and Portland Hills, Oregon. Geomorphology 109, 132-147.

Campanha, G.A.C., Sadowski, G.R., 1999. Tectonics of the southern portion of the Ribeira Belt (Apiaí Domain). Precambrian Research 98, 31-51.

Carvalho Júnior, O.A., Guimarães, R.F., Montgomery, D.R., Gillespie, A.R., Gomes, R.A.T., Martins, É.d.S., Silva, N.C., 2013. Karst depression detection using ASTER, ALOS/PRISM and SRTM-derived digital elevation models in the Bambuí group, Brazil. Remote Sensing 6, 330-351. URL: http://www.mdpi.com/2072-4292/6/1/330, doi:10.3390/rs6010330.

Christian, C.S., 1958. The concept of Land Units and Land Systems. Proceedings of the Ninth Pacific Science Congress 20, 74-81.

Christian, C.S., Paterson, S.J., Perry, R.A., Slatyer, R.O., Stewart, G.A., Traves, D.M., $1953 . \quad$ Survey of the Townsville-Bowen region, north Queensland, 1950. Land Research Series 2. CSIRO. Melbourne, Australia.

De Waele, J., Plan, L., Audra, P., 2009. Recent developments in surface and subsurface karst geomorphology: An introduction. Geomorphology 106, 1-8.

Doctor, D.H., Young, J.A., 2013. An Evaluation of Automated GIS Tools for delineating Karst Sinkholes and Closed Depressions from 1-meter LiDAR-Derived Digital Elevation Data, in: 3TH SINKHOLE CONFERENCE NCKRI SYMPOSIUM 2, pp. 449-458.

Eeckhaut, M., Poesen, J., Verstraeten, G., Vanacker, V., Nyssen, J., Moeyersons, J., Van Beek, L., Vandekerckhove, L., 2007. Use of lidar-derived images for mapping old landslides under forest. Earth Surface Processes and Landforms 32, 754-769.

Erskine, R.H., Green, T.R., Ramirez, J.a., MacDonald, L.H., 2007. Digital Elevation Accuracy and Grid Cell Size: Effects on Estimated Terrain Attributes. Soil Science Society of America Journal 71, 1371.

ESRI, 2011. ArcGIS 10.0. Environmental Systems Research Institute.

Evans, I., 1998. What do terrain statistics really mean?, in: Lane, S., Richards, K., Chandler, J. (Eds.), Landform Monitoring, Modelling and Analysis. John Wiley and Sons, Cambridge, United kingdom. chapter 6, pp. 119-138.

Ferrari, J., Hiruma, S., Karmann, I., 1998. Caracterização morfométrica de uma superfície cárstica do vale do Ribeira, São Paulo (núcleo caboclos - petar). Rev. IG São Paulo 19, 9-17.

Franklin, S., 1987. Geomorphometric processing of digital elevation models. Computers \& Geosciences 13, 603-609.

Garbrecht, J., Martz, L., 1994. Grid size dependency of parameters extracted from digital elevation models. Computers \& Geosciences 20, 85-87.

Ghuffar, S., Székely, B., Roncat, A., Pfeifer, N., 2013. Landslide displacement monitoring using 3D range flow on airborne and terrestrial LiDAR data. Remote Sensing 5, 2720-2745.

Glenn, N.F., Streutker, D.R., Chadwick, D.J., Thackray, G.D., Dorsch, S.J., 2006. Analysis of LiDAR-derived topographic information for characterizing and differentiating landslide morphology and activity. Geomorphology $73,131-148$

GRASS Development Team, 2015. Geographic Resources Analysis Support System (GRASS GIS) Software, Version 6.4. Open Source Geospatial Foundation. URL: http://grass.osgeo.org.

Grohmann, C.H., 2004. Morphometric analysis in Geographic Information Systems: applications of free software GRASS and R. Computers \& Geosciences 30, 1055-1067. doi:10.1016/j.cageo.2004.08.002.

Grohmann, C.H., Riccomini, C., Alves, F.M., 2007. SRTM-based morphotectonic analysis of the Poços de Caldas Alkaline Massif, southeastern Brazil. Computers \& Geosciences 33, 10-19. doi:10.1016/j.cageo.2006.05.002.

Grohmann, C.H., Steiner, S.S., 2008. SRTM resample with Short Distance-Low Nugget Kriging. International Journal of Geographical Information Science 22, 895-906. doi:10.1080/13658810701730152.

Guzzetti, F., Mondini, A.C., Cardinali, M., Fiorucci, F., Santangelo, M., Chang, K.T., 2012. Landslide inventory maps: New tools for an old problem. Earth-Science Reviews 112, 42-66.

Hardt, R., Rodet, J., Ferreira Pinto, S.d.A., 2010. O carste. produto de uma evolução ou processo? evolução de um conceito. Revista de Geografia v. especia, 110-124.

Hasui, Y., 2012. Sistema orogênico mantiqueira, in: Hasui, Y., Carneiro, C., Almeida, F., Bartorelli, A. (Eds.), Geologia do Brasil. Ed. Beca, São Paulo, pp. 331-374.

Hebeler, F., Purves, R.S., 2009. The influence of elevation uncertainty on derivation of topographic indices. Geomorphology 111, 4-16.

Heilbron, M., Pedrosa-Soares, A., Campos Neto, M., Silva, L., Trouw, R., Janasi, W., 2004. Província mantiqueira, in: Mantesso Neto, V., Bartorelli, A., Carneiro, C., Brito Neves, B. (Eds.), Geologia do Continente Sul-Americano: Evolução da obra de Fernando Flávio Marques de Almeida. Ed. Beca, São Paulo, pp. $203-236$.

Hengl, T., 2006. Finding the right pixel size. Computers \& Geosciences 32, 1283-1298.

Hiruma, S.T., Riccomini, C., 1999. Análise morfométrica em neotectônica: o exemplo do Planalto de Campos do Jordão, SP. Revista do Instituto Geológico 20, 5-19.

Jaboyedoff, M., Oppikofer, T., Abellán, A., Derron, M.H., Loye, A., Metzger, R., Pedrazzini, A., 2012. Use of LIDAR in landslide investigations: A review. Natural Hazards 61, 5-28.

Jenson, S.K., Domingue, J.O., 1988. Extracting topographic structure from digital elevation data for geographical information system analysis. Photogrammetric Engineering and Remote Sensing 54, 1593-1600.

Kakavas, M., Nikolakopoulos, K.G., Kyriou, A., Zagana, H., 2018. Assessment of freely available DSMs for automatic karst feature detection. Arabian Journal of Geosciences 11, 388. URL: https://doi.org/10.1007/s12517018-3654-8, doi:10.1007/s12517-018-3654-8.

Kakavas, M.P., Nikolakopoulos, K.G., Zagana, E., 2015. Karst features detection and mapping using airphotos, DSMs and GIS techniques. URL: https://doi.org/10.1117/12.2194529, doi:10.1117/12.2194529. 
Karmann, I., 1994. Evolução e dinâmica atual do sistema cárstico do alto Vale do Rio Ribeira de Iguape, sudeste do Estado de São Paulo. Tese de doutorado. Instituto de Geociências - Universidade de São Paulo. São Paulo.

Karmann, I., Ferrari, J.A., 2000. Karst and Caves of the Upper Ribeira Touristic State Park (PETAR), State of S? Paulo - Cave systems and karst topography with an unique underground scenery, in: Schobbenhaus, C., Campos, D.A., Queiroz, E.T., Winge, M., Berbert-Born, M. (Eds.), Geological and paleontological sites of Brazil.. DNPM/CPRM - Comissão Brasileira de Sítios Geológicos e Paleobiológicos (SIGEP). volume 1, pp. 401-413. URL: http://sigep.cprm.gov.br/sitio043/sitio043english.htm.

Koppen, W., 1948. Climatologia: Con un estudio de los climas de la tierra. Fundo de Cultura Economica (FCE), México.

Lindsay, J.B., Creed, I.F., 2006. Distinguishing actual and artefact depressions in digital elevation data. Computers $\&$ Geosciences 32, 1192-1204.

Lindsay, J.B., Creed, I.F., Beall, F.D., 2004. Drainage basin morphometrics for depressional landscapes. Water Resources Research 40, W09307.

McKean, J., Roering, J., 2004. Objective landslide detection and surface morphology mapping using high-resolution airborne laser altimetry. Geomorphology 57, 331-351.

Metternicht, G., Hurni, L., Gogu, R., 2005. Remote sensing of landslides: An analysis of the potential contribution to geo-spatial systems for hazard assessment in mountainous environments. Remote Sensing of Environment 98, $284-303$.

Minár, J., Evans, I.S., 2008. Elementary forms for land surface segmentation: The theoretical basis of terrain analysis and geomorphological mapping. Geomorphology 95, 236-259. doi:10.1016/j.geomorph.2007.06.003.

Mitasova, H., Hofierka, J., 1993. Interpolation by regularized spline with tension:II. Application to terrain modeling and surface geometry analysis. Mathematical Geology 25, 657-669.

Mitasova, H., Mitas, L., 1993. Interpolation by regularized spline with tension:I Theory and implementation. Mathematical Geology 25, 641-655. doi:doi:10.1007/BF00893171.

Mitasova, H., Mitas, L., Harmon, R.S., 2005. Simultaneous spline approximation and topographic analysis for lidar elevation data in open source GIS. IEEE Geoscience and Remote Sensing Letters 2, 375-379.

Modenesi-Gauttieri, M.C., Takashi Hiruma, S., Riccomini, C., 2002. Morphotectonics of a high plateau on the Northwestern flank of the continental rift of Southeastern Brazil. Geomorphology 43, 257-271.

Moore, I.D., Grayson, R.B., Ladson, a.R., 1991. Digital Terrain Modeling : A Review of Hydrological Geomorphological and Biological Applications. Hydrological Processes 5, 3-30. doi:DOI :10.1002/hyp.3360050103.

Neteler, M., Bowman, M.H., Landa, M., Metz, M., 2012. GRASS GIS: A multi-purpose open source GIS. Environmental Modelling \& Software 31, 124-130. URL: http://www.sciencedirect.com/science/article/pii/ S1364815211002775, doi:10.1016/j.envsoft.2011.11.014.

O'Leary, D.W., Friedman, J.D., Pohn, H.A., 1976. Lineament, linear, lineation: Some proposed new standards for old terms. Geological Society of America Bulletin 87, 1463-1469. doi:10.1130/0016-7606(1976)87<1463: LLLSPN> 2.0.CO;2.

Pike, R., 1995. Geomorphometry-process, practice, and prospect. Zeitschrift fur Geomorphologie Supplementband , 221-238.

Pike, R., Evans, I., Hengl, T., 2009. Geomorphometry: A brief guide, in: Hengl, T. \& Reuter, H. (Ed.), Geomorphometry: Concepts, Software, Applications. Elsevier, Amsterdam, pp. 3-30.

Planchon, O., Darboux, F., 2001. A fast, simple and versatile algorithm to fill the depressions of digital elevation models. Catena 46, 159-176.

Ponçano, W.L., 1981. Mapa geomorfológico do Estado de São Paulo, escala 1:1.000.000 (Geological Map of the São Paulo State at 1:1,000,000 scale). 1183 ed., Instituto de Pesquisas Tecnológicas do Estado de São Paulo, Divisão de Minas e Geologia Aplicada.

Ponçano, W.L., Bistrichi, C.a., Carneiro, C., Almeida, M.d., Pires Neto, A., Almeida, F.d., 1979. O conceito de sistemas de relevo aplicado ao mapeamento geomorfológico do estado de são paulo. SIMP. REG. GEOL 2, $253-262$.

Raaflaub, L.D., Collins, M.J., 2006. The effect of error in gridded digital elevation models on the estimation of topographic parameters. Environmental Modelling and Software 21, 710-732.

Riccomini, C., Velázquez, V.F., Gomes, C.B., . Tectonic controls of the Mesozoic and Cenozoic alkaline magmatism in central-southeastern Brazilian Platform, in: Gomes (Ed.), Mesozoic to Cenozoic alkaline magmatism in central-southeastern Brazilian Platform. Edusp. chapter Tectonic controls of the Mesozoic and Cenozoic alkaline magmatism in central-southeastern Brazilian Platform, pp. 31-55.

Schmidt, J., Andrew, R., 2005. Multi-scale landform characterization. Area 37, 341-350.

Schmidt, J., Hewitt, A., 2004. Fuzzy land element classification from DTMs based on geometry and terrain position. Geoderma 121, 243-256.

Smith, M.J., Wise, S., 2007. Problems of bias in mapping linear landforms from satellite imagery. International Journal of Applied Earth Observations and Geoinformation 9, 65-78. URL: http://dx.doi.org/10.1016/ j.jag.2006.07.002, doi:10.1016/j.jag.2006.07.002.

Sterzai, P., Vellico, M., Berti, M., Coren, F., Corsini, A., Rosi, A., Mora, P., Zambonelli, F., Ronchetti, F., 2010. LIDAR and Hyperspectral data integration for landslide monitoring: the test case of Valoria landslide. Italian Journal of Remote Sensing 42, 89-99.

Stokes, T., Griffiths, P., Ramsey, C., 2010. Karst Geomorphology , Hydrology , and Management. Compendium of forest hydrology and geomorphology in British Columbia , 373-400doi:10.2307/635167.

Strugale, M., Rostirolla, S.P., Mancini, F., Filho, C.V.P., Ferreira, F.J.F., de Freitas, R.C., 2007. Structural framework and Mesozoic-Cenozoic evolution of Ponta Grossa Arch, Paraná Basin, southern Brazil. Journal 
of South American Earth Sciences 24, 203-227. URL: http://www.sciencedirect.com/science/article/pii/ S0895981107000624, doi:https://doi.org/10.1016/j.jsames.2007.05.003.

Summerfield, M.A., 1991. Global Geomorphology. 1 ed., Pearson Education Limited, Edinburgh.

Wang, G., Joyce, J., Phillips, D., Shrestha, R., Carter, W., 2013. Delineating and defining the boundaries of an active landslide in the rainforest of Puerto Rico using a combination of airborne and terrestrial LIDAR data. Landslides 10, 503-513.

Wilson, J.P., Gallant, J.C., 2000. Terrain Analysis: Principles and Applications. Wiley.

Wu, Q., Deng, C., Chen, Z., 2016. Automated delineation of karst sinkholes from LiDAR-derived digital elevation models. Geomorphology 266, 1-10.

Zonneveld, I.S., 1989. The land unit - A fundamental concept in landscape ecology, and its applications. Landscape Ecology 3, 67-86. URL: https://doi.org/10.1007/BF00131171, doi:10.1007/BF00131171. 